\title{
Bacteriological profile and drug sensitivity patterns in chronic suppurative otitis media patients at J. L. N. Hospital \& Research Centre, Bhilai, Chhattisgarh State, India
}

\author{
Sonam Rathi' ${ }^{1}$, Ashwin A. Jaiswal ${ }^{2, *}$, Neeta Sharma ${ }^{3}$, P. K. Banerjee ${ }^{4}$, A. K. Garg ${ }^{5}$ \\ ${ }^{1}$ DNB Resident, ${ }^{2}$ Consultant, ${ }^{3}$ Senior Deputy Director, ${ }^{4}$ Joint Director, ${ }^{5}$ Director \& HOD, Dept. of ENT \& Head Neck Surgery, \\ Jawaharlal Nehru Hospital Research Centre, Bhilai, Chattisgarh, India
}

*Corresponding Author:

Email: ash1978jaiswal@gmail.com

\begin{abstract}
Objective: To isolate and identify various bacterial pathogens in positive ear swab cultures of CSOM cases and to determine the antibiotic sensitivity pattern of different bacterial species identified.

Study design: Prospective study

Setting: J. L. N. Hospital \& Research Centre, Bhilai (C.G).

Materials and Method: The study was done on the population of Bhilai and surrounding region. A sample size of 120 cases attending the ENT OPD with the diagnosis of Chronic Suppurative Otitis Media and active ear discharge were included in the study. Detailed history, general physical examination, local systemic examination was done along with aural swab for Gram's staining and aerobic bacterial culture and drug sensitivity. The data were then compared with the relevant $\&$ available literature.

Results: Most of the patients were in the age group of 11-20 years (38.33\%), followed by 21-30 years age group (31.67\%). More males $(60 \%)$ were affected by the disease than females $(40 \%)$. Unilateral $(59.16 \%)$ infection was more common than bilateral (40.83\%). Incidence of monobacterial (90\%) etiology was more common than polymicrobial (9.1\%). Staphylococcus aureus 67 $(51.53 \%)$ was the most commonly isolated bacteria followed by the Pseudomonas 26 (20\%). Antibiogram showed the most effective drugs in the present study are clindamycin, cotrimoxazole, ciprofloxacin, amikacin, chloramphenicol and ceftazidime

Conclusion: Staphylococcus aureus is the most common pathogen isolated, followed by Pseudomonas. Clindamycin was the most effective antibiotic followed by cotrimoxazole, ciprofloxacin, amikacin, chloramphenicol and ceftazidime. Antibiotic sensitivity of the organisms varies according to geographical area and local practice regarding the choice of antibiotics. A continuous and periodic evaluation of microbiological pattern and their antibiotic sensitivity pattern in local area is helpful in prescribing empirical antibiotics for successful treatment of otitis media and thus minimizing its complications and emergence of resistant strains.
\end{abstract}

Keywords: Chronic Suppurative Otitis Media (CSOM), antibiotic, Antibiogram, Staphylococcus aureus.

\section{Introduction}

Chronic suppurative otitis media (CSOM) is a chronic inflammation of the mucoperiosteum of the middle ear cleft which leads to abundant discharge from the ear and hearing impairment that may have a serious long term effect on language, auditory \& cognitive development and on educational progress. ${ }^{1}$

The assessment and management of CSOM presents many challenging and fascinating problems. CSOM is a disease of multiple aetiologies and is well known for its persistence and recurrence inspite of treatment. Accordingly the manifestations of CSOM are extremely variable and there may be any lesion from a small healed deformity of the Tympanic Membrane (TM), to a cholesteatoma infiltrating widely throughout the temporal bone. ${ }^{2}$ It is a destructive and persistent disease with irreversible sequelae and can proceed to serious intra and/or extra cranial complications.

The incidence of CSOM appears to depend on race and socio-economic factors. Socio-economical factors such as poor living conditions and overcrowding, poor hygiene and nutrition have been suggested as a basis for the wide spread prevalence of CSOM. CSOM has received considerable attention, not only because of its high incidence and chronicity, but also because of issues such as bacterial resistance and ototoxicity with both topical and systematic antibiotics. ${ }^{3}$

The widespread indiscriminate, haphazard use of antibiotics and poor follow up of patients has precipitated the emergence of multiple resistant strains of bacteria which can produce both primary and post operative infections. Changes in the microbiological flora following the advent of sophisticated synthetic antibiotics increase the relevance of reappraisal of the modern day flora in CSOM and their in vitro antibiotic pattern is very important for the clinician to plan a general outline of treatment for a patient with a chronically discharging ear. ${ }^{4}$ The principles of treatment such as knowledge of local microbial pattern and their drug sensitivity are essential for effective and low cost treatment. ${ }^{5}$

The changing flora of CSOM and emergence of strains resistant to the commonly employed antibiotics stimulated the study. The purpose of this study is to find the local pattern of bacteria associated with CSOM and to detect the antibiogram of the isolates.

\section{Materials and Method}

Patients attending ENT OPD at Jawaharlal Nehru Hospital and Research Centre, Bhilai, Chhattisgarh 
state form the source of the sample for study. The samples of Ear discharge of more than 6 weeks duration coming to department during Study Period of July 2012 to June 2014 constitute the material for study.120 samples were received during the study period fulfilling the following inclusion and exclusion criterias.

\section{Inclusion Criteria}

1. Patients presenting with chronic ear discharge for more than 6-12 weeks.

2. Patients with perforated tympanic membrane.

3. Patients must not have received ototopical or systemic antibiotics $(>12 \mathrm{wks})$ prior to the inclusion in the study.

\section{Exclusion Criteria}

1. Patients who have taken systemic or topical antibiotics for CSOM in last 12 wks.

2. Patients with single and first episode of ear discharge will be excluded.

3. No dry ears are included in this study.

4. Patients with serious medical conditions such as immunocompromised states, malignancy or blood dyscrasia.

5. Patients without any informed consent

Detailed history, general physical examination and local systemic examination were done for each case. Clinical data was collected using a preformed questionnaire. Two swabs were collected from patients diagnosed with CSOM using sterile cotton wool swabs and ear specula. All care was taken to avoid surface contamination with contents of External Auditory Canal (EAC). Swabs were collected in a culture tube for Gram's staining, aerobic bacterial culture and drug sensitivity, while specimen for anaerobic bacteria were taken directly into the Liquid Thioglycollate medium. All the swabs were transported to microbiology department. From the first swab direct gram staining was done followed by immediate inoculation on Blood Agar, Chocolate agar \& MacConkey Agar plates which were then kept at 37 degree Celsius for 24-48 hours. The other swab was inoculated immediately in Enriched Thioglycollate medium with indicator and transported to microbiology lab and cultured for anaerobes in it for 24-48 hours. Samples were processed and identification of sample was done by conventional methods which were Gram staining, Colony morphology\& Biochemical tests. All the organisms were subjected to antibiogram by KirbyBauer disc diffusion method. Antibiotic discs used for the sensitivity study were amikacin, gentamicin, vancomycin, clindamycin, amoxyclav, cotrimoxazole, ciprofloxacin, ceftazidime and roxithromycin.

\section{Analysis of Data (Statistical Method employed) \\ a. Percentage \\ b. Mean \& SD}

$\mathrm{MEAN}=\frac{\sum X}{N}, \mathrm{SD}=\sqrt{\frac{\sum(X i-M E A N)^{2}}{N}}$

c. Unpaired PAIRED ' $t$ ' TEST $t=$ $\frac{\text { Difference OF MEANS }}{S E}$, where $\left.\mathrm{SE}=\mathrm{CSD} * \sqrt{\left(\frac{1}{N 1}\right.}+\frac{1}{N 2}\right)$

$\mathrm{CSD}=$ Combined Standard Deviation $\left.=\sqrt{\left(\frac{S D 1^{2}}{N 1}\right.}+\frac{S D 2^{2}}{N 2}\right)$

d. Chi square value $=\sum \frac{(O-E)^{2}}{E}$ degree of freedom $=$ $(\mathrm{r}-1)(\mathrm{c}-1)$

$\mathrm{O}=$ observed Frequency

$\mathrm{E}=$ expected frequency

Level of significance was set at $\mathrm{p}<0.05$.

$\mathrm{P}$ value $<0.05$ was considered to be significant.

$P$ value $<0.01$ was considered to be highly significant

\section{Results}

In the present study of 'Bacteriological profile and drug sensitivity pattern of CSOM patients', conducted from July, 2012 to June, 2014; 120 patients fulfilling the inclusion criteria were randomly selected and analyzed.

\section{Age and Sex distribution}

Majority of the patients were of the age group 1120 years (38.33\%), among which males were more common, Followed by 21-30 years age group (31.67\%). Least number of patients were found in $>50$ years age group $(1.67 \%)$. In all the age groups males were more commonly affected, but $\mathrm{p}$ value of 0.59 depicted that there was no statistically significant association between age group of ear discharge and distribution of sex. Males $(60 \%)$ outnumbered the females $(40 \%)$ in this study with a male to female sex ratio of 1.5:1 (Graph 1). Mean age was $24.07 \pm 10.89$ in females and $23.04 \pm 10.6$ for males but no significant association of mean age with sex was noted. $(p=0.61)$. 


\section{Graph 1: Age \& Sex distribution}

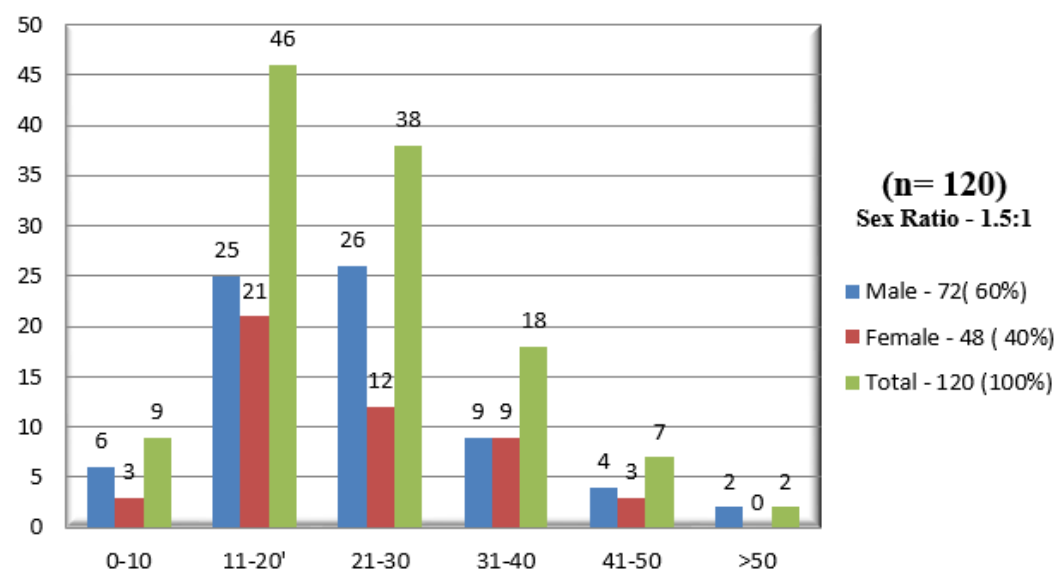

\section{Distribution of Ear Involvement}

In our study we found that disease most commonly involved unilateral ear $(59.16 \%)$ in both male $(58.33 \%)$ and female $(60.41 \%)$ subjects. $(\mathrm{p}=0.88)$. In cases of unilateral involvement slightly greater predilection for right ear $(30.8 \%)$ than left ear $(28.3 \%)$ was noticed (Graph 2). On comparing, $\mathrm{p}$ value $=0.46$ showed no significant association between the laterality of ear and age.

\section{Graph 2: Distribution of Ear Involvement}

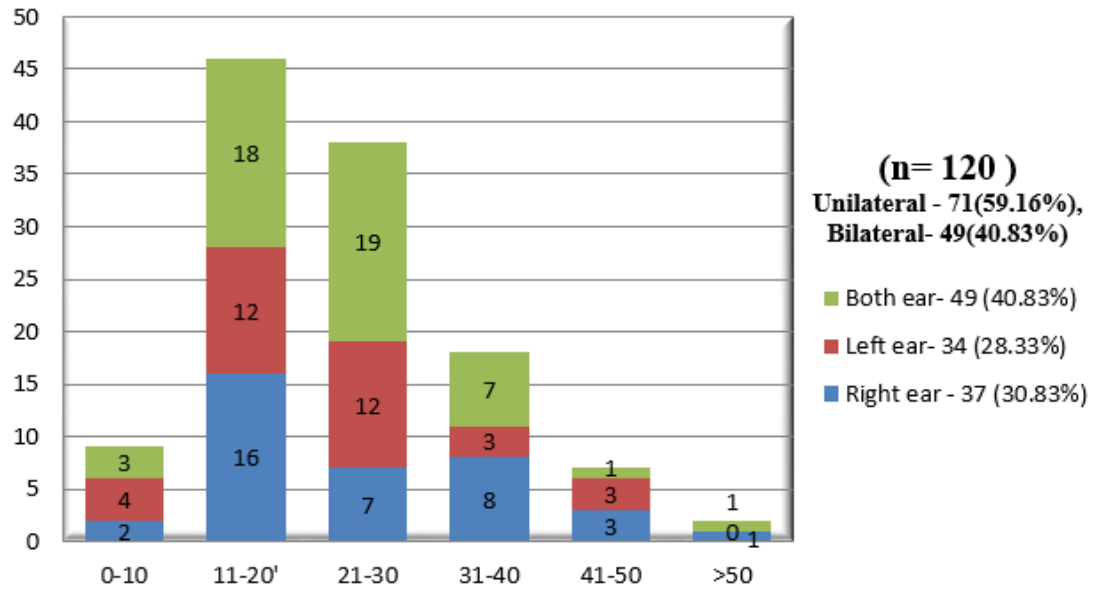

\section{Characteristics of Ear discharge}

In most of the cases patient had 1-5 years $(33.33 \%)$ history of ear discharge, only $11.67 \%$ of patients had ear discharge for $>20$ years. In most of the cases $(73.3 \%)$, discharge was of insidious onset. Out of 120 discharging ear, fluctuation was present in $77.5 \%$ cases. Discharge was moderate in maximum number $(52.5 \%)$ of cases, while it was scanty in only $19.17 \%$ cases. Mucopurulent discharge was present in most of the cases $(90 \%)$. In $74.17 \%$ it was non-foul smelling while in rest $25.83 \%$ discharge were foul smelling. Most of the patients (79.17\%) had yellow coloured discharge followed by white colour in $14.17 \%$ of cases.

\section{Culture Results}

Among the 120 patients studied, the bacteriological study was sterile in 1 case $(0.833 \%)$, a monomicrobial isolate was seen in 108 cases $(90 \%)$ while $11(9.1 \%)$ cases had polymicrobial growth. (Graph 3) 
Graph 3: Type of Bacterial culture

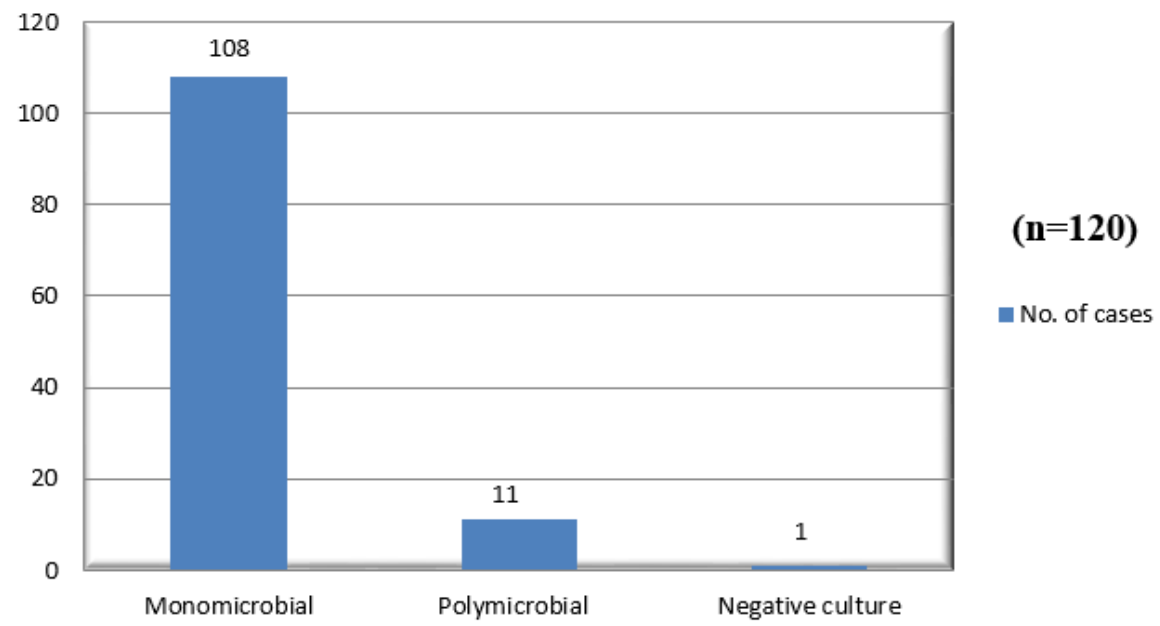

\section{Gram Staining of Isolates}

On Gram staining of isolates predominantly gram positive bacteria \{Fig. 1(a, b)\} were seen in $56.1 \%$ whereas gram negative bacteria $\{$ Fig. 2(a, b) $\}$ were seen in $43.8 \% .91 .78 \%$ of the gram positive isolates cultured Staphylococcus aureus whereas Pseudomonas $(45.61 \%)$ was the most common gram negative isolate followed by Klebsiella (19.29\%) and E. coli (17.54\%). (Graph 4)

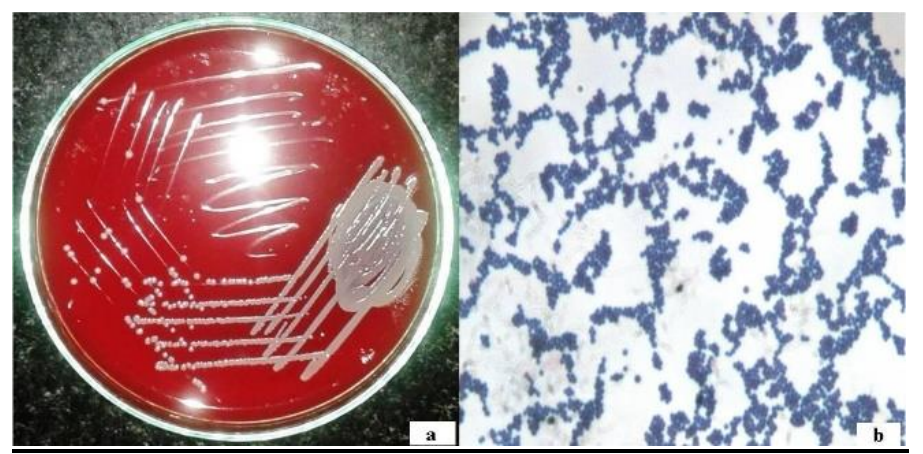

Fig. 1: (a) Blood Agar culture plate showing colonies of staphylococcal growth; (b) Gram staining of Isolates showing Gram positive cocci arranged in clusters

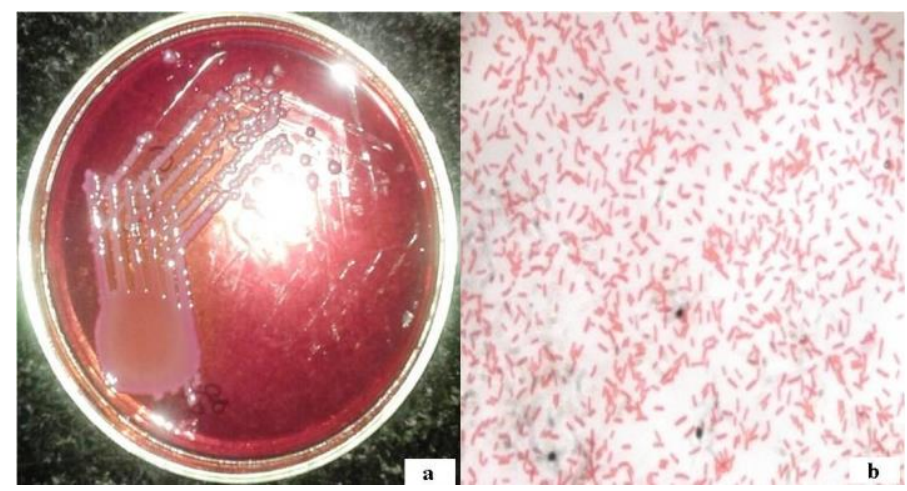

Fig. 2: (a) Mac-conkey Agar Culture plate showing colonies of lactose fermenting Gram negative microorganism; (b) Gram staining of Isolates showing Gram negative Bacilli 
Graph 4: Type of Isolates on Gram staining \& Bacteriological Profile

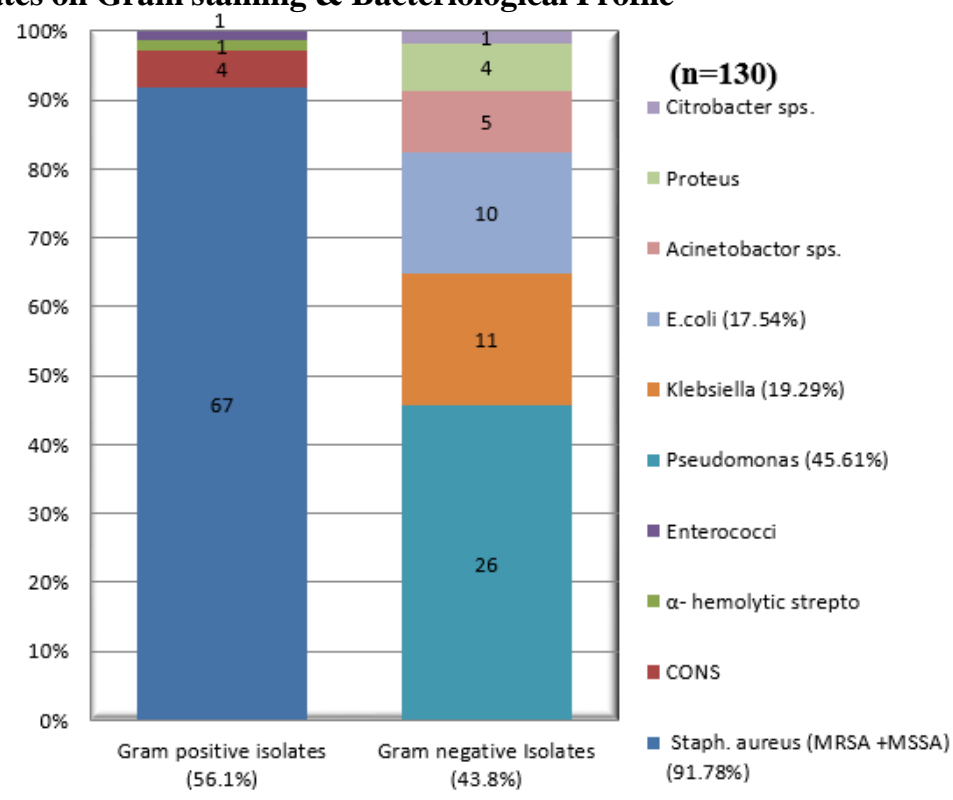

\section{Bacteriological profile of the isolates}

Total 130 bacterial isolates were recovered from the 119 positive cultures. All the isolates showed aerobic flora $(100 \%)$ and no anaerobes $(0 \%)$ were isolated in any of the culture. Staphylococcus aureus was the most common isolated bacteria, seen in 51.5\% (67) of isolates followed by the Pseudomonas sp. in $20 \%$ (26) of isolates. Among the Staphylococcus aureus isolates, $34.62 \%$ (45) were MRSA and $16.92 \%$ (22) were MSSA. Other isolates included Klebsiella sp. in $11(8.46 \%)$, E. coli in $10(7.69 \%)$, Acinetobacter in $5(3.85 \%)$, CONS and Proteus sp. in 4 (3.08\% each), and $\alpha$-haemolytic streptococcus, Citrobacter sp. \& Enterococci in $1(0.77 \%$ each) isolate. (Graph 4)

\section{Antibiotic Sensitivity Patterns}

Antibiotic sensitivity was carried out for 130 isolates by Kirby-Bauer disc diffusion method by using antibiotic discs. Most sensitive antibiotic for gram positives was clindamycin $(87.67 \%)$ followed by cotrimoxazole $(56.16 \%)$, whereas gram negative isolates showed maximum sensitivity to amikacin (59.64\%) followed by ciprofloxacin.

\section{Antibiotic Sensitivity Patterns of Gram Positive Isolates}

Antibiogram showed most of the MRSA isolates were sensitive to clindamycin (88.88\%), lincomycin $(84.44 \%)$ and vancomycin $(82.22 \%) .4 .44 \%$ were found to be resistant to all antibiotics tested. $40 \%$ isolates showed sensitivity to cotrimoxazole and fewer number to roxithromycin $(26.66 \%)$ and cloxacillin $(11.1 \%)$. MSSA showed higher sensitivity to most of the drugs, $95.45 \%$ were sensitive to clindamycin, $90.90 \%$ to ciprofloxacin and cloxacillin, $81.81 \%$ to cotrimoxazole and lincomycin. Chloramphenical and roxithromycin showed sensitivity in $77.27 \%$ cases. 3 (75\%) out of 4 CONS isolates showed sensitivity to cotrimoxazole, amoxicillinclavulinic acid, cloxacillin, clindamycin. 50\% of the isolates were sensitive to ciprofloxacin, chloramphenicol, ceftazidime and $25 \%$ to roxithromycin \& lincomycin. Single isolate of $\alpha$ - haemolytic streptococcus was isolated from the culture, which showed $100 \%$ sensitivity to ciprofloxacin, cotrimoxazole, chloramphenicol, cloxacillin, ceftazidime, amoxicillin-clavulinic acid, vancomycin, lincomycin. Enterococci showed 100\% sensitivity to cotrimoxazole and vancomycin. (Table 1)

Table 1: Antibiotic Sensitivity Patterns of Gram Positive Isolates (Antibiogram) (Number of isolates and percentage of each organism sensitive to various antibiotics)

\begin{tabular}{|l|c|l|l|l|l|}
\hline & MRSA & MSSA & CONS & $\begin{array}{l}\text { a-hemolytic } \\
\text { streptococci }\end{array}$ & Enterococci \\
\hline Roxithromycin & $12(26.66 \%)$ & $17(77.27 \%)$ & $1(25 \%)$ & & \\
\hline Vancomycin & $37(82.22 \%)$ & $16(72.72 \%)$ & $2(50 \%)$ & $1(100 \%)$ & $1(100 \%)$ \\
\hline Clindamycin & $40(88.88 \%)$ & $21(95.45 \%)$ & $3(75 \%)$ & & \\
\hline Lincomycin & $38(84.44 \%)$ & $18(81.81 \%)$ & $1(25 \%)$ & $1(100 \%)$ & \\
\hline Cotrimoxazole & $18(40 \%)$ & $18(81.81 \%)$ & $3(75 \%)$ & $1(100 \%)$ & $1(100 \%)$ \\
\hline Ciprofloxacin & & $20(90.9 \%)$ & $2(50 \%)$ & $1(100 \%)$ & \\
\hline Cloxacillin & $5(11.11 \%)$ & $20(90.9 \%)$ & $3(75 \%)$ & $1(100 \%)$ & \\
\hline
\end{tabular}




\begin{tabular}{|l|l|c|c|c|l|}
\hline Amoxyclav & & $11(50 \%)$ & $3(75 \%)$ & $1(100 \%)$ & \\
\hline Chloramphenicol & & $17(77.27 \%)$ & $2(50 \%)$ & $1(100 \%)$ & \\
\hline Gentamicin & & $4(18 \%)$ & & & \\
\hline Ceftazidime & & $15(68.18 \%)$ & $2(50 \%)$ & $1(100 \%)$ & \\
\hline Cefixime & & $2(9.09 \%)$ & & & \\
\hline Piperacillin & & $1(4.54 \%)$ & & & \\
\hline Resistant to all & $2(4.44 \%)$ & & $1(25 \%)$ & & \\
\hline
\end{tabular}

\section{Antibiotic Sensitivity Patterns of Gram Negative Isolates}

46.15\% Pseudomonas isolates were found to be sensitive to amikacin and $30.76 \%$ to gentamicin. Ceftazidime and ciprofloxacin were sensitive in $34.61 \%$ of isolates. Amoxicillin-clavulinic acid showed lower sensitivity, in $3.84 \% .4(15.38 \%)$ of the isolates were found to be resistant to all the antibiotics tested. All the Klebsiella isolates were found to be sensitive to amikacin (100\%). 90.90\% were sensitive to chloramphenicol and $81.81 \%$ to ciprofloxacin. Lesser number of isolates were sensitive to gentamicin (63.63\%), cotrimoxazole $(45.45 \%)$, ceftazidime $(36.36 \%)$ and amoxicillinclavulinic acid $(18.18 \%) .90 \%$ of the E. coli isolates showed sensitivity to amikacin, $70 \%$ to chloramphenicol,
$60 \%$ to ciprofloxacin and $50 \%$ to gentamicin. Lesser number isolates showed sensitivity to ceftazidime and cotrimoxazole (in $40 \%$ isolates) \& $20 \%$ to amoxicillinclavulinic. All the Acinetobacter isolates were sensitive to ceftazidime and cotrimoxazole (100\%). Only $40 \%$ isolates showed sensitivity to chloramphenicol. Out of the 4 Proteus isolates $3(75 \%)$ were sensitive to ciprofloxacin, cotrimoxazole, gentamicin and ceftazidime. $50 \%$ were sensitive to amikacin and chloramphenicol. Only 25\% isolates showed sensitivity to amoxicillin-clavulinic acid and piperacillin. Single Citrobacter isolate which was isolated showed 100\% sensitivity to chloramphenicol and amoxicillin-clavulinic acid. (Table 2)

Table 2: Antibiotic Sensitivity Patterns of Gram Negative Isolates (Antibiogram) (Number of isolates and percentage of each organism sensitive to various antibiotics)

\begin{tabular}{|l|c|c|c|c|c|c|}
\hline & $\begin{array}{c}\text { Pseudomonas } \\
\text { sps. }\end{array}$ & $\begin{array}{c}\text { Klebsiella } \\
\text { sps. }\end{array}$ & E.coli & $\begin{array}{c}\text { Acinetobacter } \\
\text { sps. }\end{array}$ & $\begin{array}{c}\text { Proteus } \\
\text { sps. }\end{array}$ & $\begin{array}{c}\text { Citrobacter } \\
\text { sps. }\end{array}$ \\
\hline Cotrimoxazole & $4(15.38 \%)$ & $5(45.45 \%)$ & $4(40 \%)$ & $5(100 \%)$ & $3(75 \%)$ & \\
\hline Ciprofloxacin & $9(34.61 \%)$ & $9(81.81 \%)$ & $6(60 \%)$ & & $3(75 \% 0$ & \\
\hline Amoxyclav & $1(3.84 \%)$ & $2(18.18 \%)$ & $2(20 \%)$ & & $1(25 \%)$ & $1(100 \%)$ \\
\hline Chloramphenicol & $6(23.07 \%)$ & $10(90.9 \%)$ & $7(70 \%)$ & $2(40 \%)$ & $2(50 \%)$ & $1(100 \%)$ \\
\hline Amikacin & $12(46.15 \%)$ & $11(100 \%)$ & $9(90 \%)$ & & $2(50 \%)$ & \\
\hline Gentamicin & $8(31 \%)$ & $7(64 \%)$ & $5(50 \%)$ & & $3(75 \%)$ & \\
\hline Ceftazidime & $9(34.61 \%)$ & $4(36.36 \%)$ & $4(40 \%)$ & $5(100 \%)$ & $3(75 \%)$ & \\
\hline Piperacillin & $4(15.38 \%)$ & & $1(10 \%)$ & & $1(25 \%)$ & \\
\hline $\begin{array}{l}\text { Moderate } \\
\text { Sensitivity to } \\
\text { Amikacin }\end{array}$ & $1(3.84 \%)$ & & & & & \\
\hline Resistant to all & $4(15.38 \%)$ & & & & & \\
\hline
\end{tabular}

\section{Discussion}

Due to changing pattern of bacteriological profile of Otitis media and sensitivity of microorganisms towards antibiotics, it has become very important to find out the organism causing the disease.

High prevalence of culture positive cases of CSOM $(91.18 \%)$ was seen in the present study. It was found that the prevalence of CSOM was higher in the age group of $11-20$ years $(38.33 \%)$, followed by 21-30 years $(31.67 \%)$. These findings are in correlation with mentioned workers in Table 3. However Rao B.N. et al, ${ }^{9}$ Taneja M.K. et al, ${ }^{10}$ Iseh K.R. et al $(75.43 \%),{ }^{11}$ Mariam et al $(39.2 \%){ }^{12}$ have reported maximum number of patients in first decade. According to study of Poorey V $\mathrm{K} \&$ Iyer $\mathrm{A}^{4}$ common age group was first and second decade of life, but among them 1-10years age group was more common. Agrawal et $\mathrm{al}^{13}$ also reported highest incidence in $0-20$ year age group $(62.4 \%)$. Vineetha Gupta et al, ${ }^{14}$ Loy A.H.C. et al, ${ }^{5}$ Gh Ettehad et al $(26.22 \%)^{15}$ and Shamweel Ahmad $(31.70 \%){ }^{16}$ have reported maximum number of patients in third decade. Incidence of CSOM decreases as the age advances.

Males were more affected, $72(60 \%)$ than the females $48(40 \%)$ in the present study. This finding is correlated with other series (Table 4) Shrestha B L et al ${ }^{20}$ found the female predominance (55.2\%), also supported by Prakash $\mathrm{M}$ et al $(55 \%){ }^{21}$ The male predominance may be because of their more exposed way of life. ${ }^{22}$

In the present study unilateral infection $(59.16 \%)$ was more common compared to bilateral infection $(40.83 \%)$. Our findings are correlated with other studies. 
(Table 5) Right and left ears were found to be equally affected in our study ( $30.83 \%$ vs $28.33 \%)$.

The onset of ear discharge was insidious in about $73.33 \%$ of patients, while in $26.67 \%$ it was of sudden onset. The discharge was fluctuant with intermittent discharge in about $77.5 \%$ of cases while fluctuation was not seen in $22.5 \%$ of cases. In most of the cases discharge was moderate in amount (52.5\%), mucopurulent $(90 \%)$ in character and non foul smelling $(74.17 \%)$. In some cases discharge was profuse or scanty. These findings are consistent with as mentioned by Mills ${ }^{28}$ Chowdhury and Alauddin, ${ }^{29}$ Hamilton J [30] and Youngs. ${ }^{31}$

In the present study $119(99.1 \%)$ specimens were positive and $1(0.83 \%)$ was negative for the culture. The culture results are variable compared to other workers. (Table 6)

Negative cultures can be attributed to Non-bacterial growth, anaerobic growth, Prior-antibiotic therapy, Presence of antimicrobial enzymes i.e. lysozyme alone or in combination with immunoglobulins that suppress the bacterial growth. . $^{18,33,34}$

In the present study monomicrobial etiology was $108(90 \%)$ and polymicrobial was $11(9.1 \%)$ which is correlated with the other studies. (Table 7) However Rama Rao M.V. et $\mathrm{al}^{36}$ found equal incidence of mixed and pure culture and Baruah P.C. et $\mathrm{al}^{37}$ found predominance of mixed culture. Availability and use of topical and systemic broad spectrum antibiotics in the period before consultation was probably responsible for the lower incidence of mixed infection.

All the isolated microorganisms were aerobes $(100 \%)$, no anaerobes were isolated. Although this is in contrast to most of the previous studies but Gh Ettehad et al ${ }^{15}$ study is coherent with this finding.

The finding of predominant gram positive bacteria in $73(56.15 \%)$ out of 130 isolates is consistent with few of the previous studies such as Marium et $\mathrm{al}^{12}$ in their study predominantly reported gram positive bacteria in 30 isolates (65.2\%) and Shamweel Ahmad ${ }^{16}$ in his study found $102(62.19 \%)$ gram positive isolates.

Among the organisms isolated, Staphylococcus aureus was the predominant organism 67 (51.53\%) followed by Pseudomonas spp. 26 (20\%). This finding is correlated with other studies. (Table 8) However workers like Arya S.C. et al. ${ }^{17}$ Nandy A. et al, ${ }^{18}$ Grewal R.S. et al ${ }^{41}$ Urmil Mohan et al, ${ }^{25}$ Hiremath S.L. et al, ${ }^{33}$ Loy A.H.C. et $\mathrm{al}^{5}$ have found Staphylococcus aureus as the second most common organism causing CSOM. Some of the studies conducted by Ballal M. et al, ${ }^{42}$ Saurabh V. et $\mathrm{al}^{43}{ }^{43}$ Hiremath S.L. et $\mathrm{al}^{33}$ and Loy A.C. ${ }^{5}$ have found Pseudomonas spp. as the predominant organism causing CSOM.
The next most common organism was Klebsiella spp. $11(8.46 \%)$ in the present study and Proteus species were isolated from 4(3.07\%) cases However, Singh N. et $\mathrm{al}^{34}{ }^{34}$ Rama Rao M.V. et $\mathrm{al}^{36}$ and Saurabh V. et $\mathrm{al}^{43}$ have found them as the second most leading cause for CSOM.

In the present study Enterococcus spp. was isolated in $1(0.77 \%)$ cases. Other workers who have isolated Enterococci in CSOM are Hiremath S.L. et $\mathrm{al}^{33}$ in $0.79 \%$ cases and Loy A.H.C. et $\mathrm{al}^{5}$ in $2.2 \%$ cases. E. coli was isolated in $10(7.69 \%)$ cases in the present study. However Rama Rao M.V. et $\mathrm{al}^{36}$ has reported a high incidence of E. coli, i.e. $18.7 \%$ cases.

In the present study CONS was isolated in 4 $(3.07 \%)$ cases. However many workers have found higher incidence of CONS like Srivastava V.K. et $\mathrm{al}^{23}$ in $10.2 \%$ cases, Rama Rao M.V. et a ${ }^{36}$ in $21.6 \%$ cases and Loy A.H.C. et al ${ }^{5}$ in $21.1 \%$ cases.

The frequency of Staphylococcus aureus in the middle ear infections can be attributed to their ubiquitous nature and high carriage of resistant strains in the external auditory canal and upper respiratory tract.

The organisms like Pseudomonas spp. and Proteus spp. are considered mostly as secondary invaders from external auditory canal gaining access to the middle ear via a defect in tympanic membrane resulting from an acute episode of otitis media. Organisms like E. coli and Klebsiella spp. become opportunistic pathogens in the middle ear when resistance is low.

Although CONS are generally considered as nonpathogenic, their association in some cases can be attributed to the extreme lowering of resistance in middle ear due to invasion by other organisms. Under these circumstances they assume pathogenic role either singly or more often in combination with other organisms. ${ }^{1}$

In the present study $49.23 \%$ of organisms were sensitive to clindamycin, followed by cotrimoxazole $(47.69 \%)$, ciprofloxacin $(38.46 \%)$, chloramphenicol (36.92\%), ceftazidime $(33.07 \%)$.The most effective antibiotic against gram positive bacteria was found to be clindamycin $(87.67 \%)$, followed by cotrimoxazole (56.16\%) and cloxacillin (39.7\%). Amongst gram negative bacteria most sensitive antibiotic was amikacin $(59.64 \%)$ followed by ciprofloxacin $(47.36 \%)$. Thus the most effective drugs in the present study are clindamycin, cotrimoxazole, ciprofloxacin, amikacin, chloramphenicol and ceftazidime. Similar sensitivity pattern was reported by Gulati et al, ${ }^{24}$ S.Varshney et $\mathrm{al}^{43}$ and Hiremath S.L.et al. ${ }^{33}$ However Nandy A. et al ${ }^{18}$ and Rao B.N. et $\mathrm{al}^{9}$ have found gentamicin as the most effective drug. In the present study majority of the isolates showed multiple drug resistance for amoxicillinclavulinic acid and cefixime. 7 (5.3\%) isolates showed resistance to all the antibiotics tested. 
Table 3: Age wise distribution

\begin{tabular}{|c|c|c|c|}
\hline Study series & Year & $\begin{array}{l}\text { Total no. Of patients in } \\
11-20 \text { years age group }\end{array}$ & Percentage \\
\hline Swarooprani N.B. et $\mathrm{al}^{6}$ & 2013 & 30 & $31 \%$ \\
\hline Rajat Prakash et al ${ }^{7}$ & 2014 & 54 & $26.47 \%$ \\
\hline Naz Perween et $\mathrm{al}^{8}$ & 2014 & 23 & $29.8 \%$ \\
\hline Present study & $2012-14$ & 46 & $38.33 \%$ \\
\hline
\end{tabular}

Table 4:- Sex wise distribution

\begin{tabular}{|c|c|c|c|}
\hline Study Series & Year & $\begin{array}{c}\text { Total no. of male } \\
\text { patients }\end{array}$ & Percentage \\
\hline Arya S C et al ${ }^{17}$ & 1966 & 116 & $70.13 \%$ \\
\hline Nandy A et al ${ }^{18}$ & 1991 & 77 & $52.74 \%$ \\
\hline Taneja M K et al $^{10}$ & 1995 & 470 & $71.87 \%$ \\
\hline Srivastava $\mathrm{A}$ et $\mathrm{al}^{19}$ & 2010 & 62 & $56.3 \%$ \\
\hline Swarooprani N B ${ }^{6}$ & 2014 & 56 & $56.6 \%$ \\
\hline Agrawal et al $^{13}$ & 2014 & 67 & $53.6 \%$ \\
\hline Present study & 2012-14 & 72 & $60 \%$ \\
\hline
\end{tabular}

Table 5: Side wise distribution

\begin{tabular}{|c|c|c|}
\hline Study series & Year & Affected unilaterally (\%) \\
\hline Srivastava et $\mathrm{al}^{23}$ & 1979 & $92.61 \%$ \\
\hline Gulati et $\mathrm{al}^{24}$ & 1997 & $80 \%$ \\
\hline Urmil Mohan et al ${ }^{25}$ & 1998 & $86.3 \%$ \\
\hline Rakesh Kumar et al $^{26}$ & 2013 & $79.13 \%$ \\
\hline Hirapure P.V. et al ${ }^{27}$ & 2014 & $71.42 \%$ \\
\hline Present study & $2012-14$ & $59.16 \%$ \\
\hline
\end{tabular}

Table 6: Culture results of cases studied

\begin{tabular}{|c|c|c|c|}
\hline Study series & Year & $\begin{array}{c}\text { Positive culture } \\
\text { no. }(\%)\end{array}$ & $\begin{array}{c}\text { Negative } \\
\text { culture }(\%)\end{array}$ \\
\hline Srivastava $\mathrm{V} \mathrm{K}$ et $\mathrm{al}^{23}$ & 1979 & $99(97.05 \%)$ & $3(2.94 \%)$ \\
\hline Nandy A et al ${ }^{18}$ & 1991 & $356(92.70 \%)$ & $28(7.29 \%)$ \\
\hline Taneja M K et al ${ }^{10}$ & 1995 & $618(84 \%)$ & $118(16 \%)$ \\
\hline Gulati et a ${ }^{24}$ & 1997 & $78(78 \%)$ & $22(22 \%)$ \\
\hline Srivastava $\mathrm{A}$ et al ${ }^{19}$ & 2010 & $90(80.3 \%)$ & $22(19.7 \%)$ \\
\hline Singh A H et al ${ }^{32}$ & 2012 & $142(94.6 \%)$ & $8(5.33 \%)$ \\
\hline 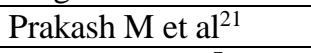 & 2013 & $75(93.75 \%)$ & $5(6.25 \%)$ \\
\hline Prakash $\mathrm{R}$ et al $^{7}$ & 2014 & $186(91.18 \%)$ & $18(8.82 \%)$ \\
\hline Present study & 2012-2014 & $119(99.1 \%)$ & $1(0.83 \%)$ \\
\hline
\end{tabular}

Table 7: Incidence of pure and mixed cultures

\begin{tabular}{|l|c|c|c|}
\hline \multicolumn{1}{|c|}{ Study series } & Year & $\begin{array}{c}\text { Monomicrobial } \\
\text { no. (\%) }\end{array}$ & $\begin{array}{c}\text { Polymicrobial } \\
\text { no. (\%) }\end{array}$ \\
\hline Arya S C et al $^{17}$ & 1966 & $129(83.77 \%)$ & $25(16.23 \%)$ \\
\hline Srivastava et al $^{23}$ & 1979 & $84(82.3 \%)$ & $12(11.7 \%)$ \\
\hline Taneja M K et al $^{10}$ & 1995 & $594(80.7 \%)$ & $24(3.3 \%)$ \\
\hline Srivastava et al & & $73(81.1 \%)$ & $17(18.9 \%)$ \\
\hline Singh A H et al $^{32}$ & 2010 & $96(64 \%)$ & $46(30.67 \%)$ \\
\hline Nageshwari et al $^{35}$ & 2012 & $84(69.4 \%)$ & $37(30.57 \%)$ \\
\hline Prakash M et al & & & \\
\hline Prakash R et al & 2012 & $64(85 \%)$ & $12(13 \%)$ \\
\hline Present study & 2014 & $118(57.84 \%)$ & $68(33.33 \%)$ \\
\hline
\end{tabular}


Table 8: Commonest organism isolated

\begin{tabular}{|c|c|c|c|}
\hline Study series & Year & $\begin{array}{l}\text { Commonest isolate } \\
(\%)\end{array}$ & $\begin{array}{l}\text { Second commonest } \\
(\%)\end{array}$ \\
\hline Iseh $\mathrm{K} \mathrm{R}$ et al $^{11}$ & 2004 & Staph aureus (46.2\%) & E. coli $(23.1 \%)$ \\
\hline Patricia N Ayson et al ${ }^{38}$ & 2006 & Staph aureus $(50 \%)$ & Pseudomonas (33.3\%) \\
\hline Gh Ettehad et al ${ }^{15}$ & 2006 & Staph aureus (31.15\%) & Pseudomonas (26.23\%) \\
\hline Nikakhlagh et $\mathrm{al}^{39}$ & 2008 & Staph aureus $(32.4 \%)$ & Pseudomonas (21.6\%) \\
\hline Srivastava $\mathrm{A}$ et $\mathrm{al}^{19}$ & 2010 & Staph aureus $(29.2 \%)$ & Pseudomonas (28.3\%) \\
\hline Mozafari et $\mathrm{al}^{40}$ & 2011 & Staph aureus (50.3\%) & Pseudomonas (23.4\%) \\
\hline Singh A H et al ${ }^{32}$ & 2012 & Staph aureus $(36 \%)$ & Proteus $(32 \%)$ \\
\hline Nageswari et al ${ }^{35}$ & 2012 & Staph aureus $(42 \%)$ & Pseudomonas (17\%) \\
\hline Mariam et $\mathrm{al}^{12}$ & 2013 & Staph aureus $(65.2 \%)$ & Pseudomonas (15.2\%) \\
\hline Shamweel Ahmad ${ }^{16}$ & 2013 & Staph aureus (56.7\%) & Pseudomonas (19.5\%) \\
\hline Prakash $\mathrm{M}$ et al ${ }^{21}$ & 2013 & Staph aureus $(41.25 \%)$ & Pseudomonas (37.5\%) \\
\hline Swarooprani N B et al ${ }^{6}$ & 2014 & Staph aureus $(29.23 \%)$ & Pseudomonas (21.4\%) \\
\hline 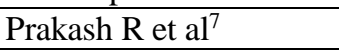 & 2014 & Staph aureus (48.69\%) & Pseudomonas (19.89\%) \\
\hline Naz Perween et al ${ }^{8}$ & 2014 & Staph aureus $(40.2 \%)$ & Pseudomonas (29.8\%) \\
\hline Agrawal et al ${ }^{13}$ & 2014 & Staph aureus (37.6\%) & Pseudomonas (32.8\%) \\
\hline Present study & 2012-2014 & Staph aureus $(51.53 \%)$ & Pseudomonas (20\%) \\
\hline
\end{tabular}

\section{Conclusion}

\section{In our geographical area}

1. Aerobic bacterial infection is common, with Gram positives out numbering Gram negatives. Staphylococcus aureus is the most common pathogen isolated, followed by Pseudomonas.

2. Clindamycin was the most effective antibiotic followed by cotrimoxazole, ciprofloxacin, amikacin, chloramphenicol and ceftazidime. Thus Sensitivity to older antibiotics is again emerging, as with more and more use of newer antibiotics and in resistant cases, these can be another good option.

3. Antibiotic sensitivity of the organisms varies according to geographical area and local practice regarding the choice of antibiotics. Thus pre-culture antibiotic should be active against both Gram positive and negative bacteria.

4. Timely diagnosis and treatment of upper respiratory tract infections, during childhood can prevent chronic suppurative otitis media and its complications later in life; hence awareness among people for seeking earlier medical opinion \& treatment should be created.

5. With the development and widespread use of antibiotics, the types of pathogenic microorganisms and their resistance to antibiotics have changed. Thus Antibiotics should be used judiciously alongwith avoiding over the counter antibiotics to prevent development of resistance

6. The most important factor responsible for the development of antibiotic resistance is human negligence. As soon as, symptoms subside, patients stop taking antibiotics before completion of therapy and allow partially resistant microbes to flourish. Such practice should be discouraged and patients should be educated to avoid the same.
7. A continuous and periodic evaluation of microbiological pattern and their antibiotic sensitivity pattern in local area is helpful in building an antibiotic policy, prescribing empirical antibiotics for successful treatment of otitis media and minimizing its complications and emergence of resistant strains as well as in long term, reduces the burden of the infection and cost of treatment on the patient.

\section{Compliance with Ethical Standards}

All the accepted principles of ethical and professional conduct have been followed and compliance is maintained. All the authors have contributed equally in the study.

\section{Disclosure of potential conflicts of interest}

All the authors have filled the potential conflict of interest disclosure forms and declare that they have no conflict of interest.

\section{Funding: Nil \\ Conflict of Interest: Nil}

Ethical approval: All procedures performed in studies involving human participants were in accordance with the ethical standards of the institutional and/or national research committee and with the 1964 Helsinki declaration and its later amendments or comparable ethical standards.

\section{Informed consent}

Informed consent was obtained from all individual participants included in the study. 


\section{References}

1. Healy GB, Roshe KW. Otitis media and middle ear effusions. In: Snow, Ballenger JJ, editors. Ballenger's otorhinolaryngology Head Neck Surgery. (16 $\left.{ }^{\text {th }} \mathrm{Ed}\right) . \mathrm{BC}$ Decker Inc 2003:249-60.

2. J Ballantyne, Groves J, editors. Scott Brown's diseases of the ear, nose and throat. $4^{\text {th }}$ ed. London: Butterworths 1979.

3. Haynes, D.S. Perioperative antibiotics in chronic suppurative otitis media. Ear Nose Throat J 2002;81:13-5.

4. Poorey V K, Iyer A. Study of Bacterial flora in Chronic Suppurative Otitis Media and its clinical significance. Ind $J$ Otolaryngol Head Neck Surg 2002;54:91-5.

5. Loy AHC, Tan AL, Lu PKS. Microbiology of chronic suppurative otitis media in Singapore. Singapore Med J 2002;43(6):296-9.

6. Swarooprani NB, Kardesai SG, Metgud SC. Aerobic Bacteriological Study of Chronic Suppurative Otitis Media with Reference to MRSA and ESBL. SMU Med J 2014;1(1):120-8.

7. Prakash R, Juyal D, Negi V, Pal S, Adekhandi S, Sharma M, Sharma N. Microbiology of Chronic Suppurative Otitis Media in a Tertiary Care Setup of Uttarakhand State. Ind North Am J Med Sci 2013;5(4):282-7.

8. Naz Perween, Kamlakant, Sehgal S, Prakash S K. Aerobic Bacteriology of Chronic Suppurative Otitis Media(CSOM) in A Tertiary Care Hospital in North India. J Med Sci Clin Res 2014;2(2):395-8.

9. Rao BN, Reddy MS. Chronic suppurative otitis media - A prospective study. IJO \& HNS 1994;3(2):72-7.

10. Taneja MK. Contributing factors in otitis media. Ind J Otol 1999;5(3):111-4.

11. Iseh K R, Abubakar TS; Chronic suppurative otitis media: A clinical profile in Sokoto, Nigeria; Sahel Med J 2003;6(3);75-8.

12. Mariam, Khalil A, Mir A, Jan M, Imran R, Shah G, Farmanullah, Latif A. Prevalence of Bacteria in Chronic Suppurative Otitis Media Patients and Their Sensitivity Patterns against Various Antibiotics in Human Population of Gilgit. Pak J Zool 2013;45(6):1647-53.

13. Agrawal A, Dharmendra K, Ankur G, Sapna G, Namrata S, Gaurav K. Microbiological profile and their antimicrobial sensitivity pattern in patients of otitis media with ear discharge. Ind J Otol 2013;19(1):5-8.

14. Vineetha Gupta, Abhay Gupta, Sivarajan K. Chronic suppurative otitis media; An aerobic microbiological study. Ind J Otol 1998;4(2):79-82.

15. Ettehad Gh, Refahi S, Nemmati A, Pirzadeh A, Daryani A. Microbial and Antimicrobial Susceptibility patterns from Patients with Chronic Otitis Media in Ardebil. Int J Tropical Med 2006;1(2):62-5.

16. Shamweel A. Antibiotics in chronic suppurative otitis media: A bacteriologic study. Egypt J Ear Nose Throat Allied Sci 2013;14:191-4.

17. Arya SC, Mohapatra LN. Bacteriological and mycotic flora in cases of chronic suppurative otitis media. J Ind Med Asso 1966;47(8):369-72.

18. Nandy A, Mully PS, Sivarajan K. Chronic suppurative otitis media - A bacteriological study. Ind J Otolaryngol 1991;43(3):136-8.

19. Srivastava.A, Singh.R.K.et al, Microbiological evaluation of active tubotympanic type of chronic suppurative otitis media, Nepalese J ENT Head Neck Surg 2010;1 (2);14-6.

20. Shrestha et al. Microbiological Profile of Chronic Suppurative Otitis Media. Nepalese J ENT Head Neck Surg 2011;2(2):6-7.

21. Prakash M, Lakshmi K, Anuradha S, Swathi GN. Bacteriological profile and their antibiotic susceptibility pattern of cases of chronic suppurative otitis media. Asian $J$ Pharm Clin Res 2013;6(3):210-2.

22. Rinaldo F Canalis, Paul R Lambert. The ear; Comprehensive otology. Philadelphia: Lipponcott Williams and Wilkins; 2000;409-431.

23. Srivastava VK, Agarwal SK, Malik G. Chronic suppurative otitis media in 1979;46(3\&1):363-7.

24. Gulati, Sudesh Kumar. Investigative profile in patients of chronic suppurative otitis media. Ind J Otol 1997;3(2):5962.

25. Mohan Urmil, Jindal Neerja. Fungal and bacterial flora of chronic suppurative otitis media in Amritsar. IJO \& HNS 1998;50(2):175-77.

26. Kumar R, Srivastava P, Sharma M, Rishi S, Nirwan P S, Hemwani K, Dahiya S. Isolation And Antimicrobial Sensitivity Profile Of Bacterial Agents In Chronic Suppurative Otitis Media Patients At Nims Hospital, Jaipur. Int J Pharm Biol Sci 2013;3(4):265-9.

27. Hirapure P.V, Pote M.K. Microbial Profile and Antibiograms of Active Patients of Chronic Suppurative Otitis Media in Latur, Maharashtra, India. Int Res J Med Sci 2014;2(5):6-9.

28. Mills R P. Management of chronic suppurative otitis media. In: Scott-Brown's otolaryngology $6^{\text {th }}$ ed. Edited by Kerr AG. Butterworth-Heinemann Oxford, Great Britain. 1997; 3: 3/10/1-11.

29. Chowdhury M A, Alauddin M. Comparative study between tubotympanic and atticoantral types of chronic suppurative otitis media. Bangladesh Med Res Counc Bull 2002;28(1):36-44.

30. Hamilton J. Chronic otitis media in Childhood. In: ScottBrown's Otolaryngology, Head and Neck Surgery, $7^{\text {th }}$ ed., edited by Gleeson M. Edward Arnold 2008;1:928-64.

31. Youngs R. Chronic suppurative otitis media-mucosal disease. In: Diseases of the ear, $6^{\text {th }}$ ed. Edited by Ludman $\mathrm{H}$ and Wright T. Arnold Publishers, London. 1998:374-85.

32. AH Singh, R Basu, A Venkatesh. Aerobic bacteriology of chronic suppurative otitis media in Rajahmundry, Andhra Pradesh, India. Biol Med 2012;4(2):73-9.

33. Hiremath SL, Kanta RC, Yeshwanathrao M, Vasantha Kumar CM. Aerobic bacterial isolates of CSOM and their antibiotic sensitivity pattern. The Indian Practitioner 2001;54(7):486-9.

34. Singh N, Bhaskar Radha. Microbiological study of otitis media. Ind J Otol 1972;24(4):161-3.

35. Nageswari R Gandham et al. Microbial profile of Ottorhoea in Patients attending OPD in a tertiary care hospital; JPBMS 2012;20(17).

36. Rama Rao MV, Jayakar PA. Bacteriological study of chronic suppurative otitis media. Ind J Med Asso 1980;75:30-3.

37. Baruah PC, Agarwal SC, Arora MML, Mehra YN. Clinical and microbiological studies in suppurative otitis media. Ind J Otol 1972; 24(4):157-9.

38. Patricia N. Ayson, Jan Eero G. Lopez, Erasmo Gonzalo DV Llanes, Chronic Suppurative Otitis Media: Bacteriology and Drug Sensitivity Patterns at the Quirino Memorial Medical Center (2004-2005): A Preliminary Study. Philipp J Otolaryngol Head Neck Surg 2006;21(1,2):20-3.

39. S. Nikakhlagh et al. Microbiologic findings in patients with CSOM; J Med Sci 2008; 8(5):503-6.

40. K Mozafari Nia, G Sepehri, H Khatmi, MR Shakibaie. Isolation and antimicrobial susceptibility of bacteria from chronic suppurative otitis media patients in Kerman, Iran; Iran Red Crescent Med J 2011;13(12):891-4. 
41. Grewal RS, Ram Shobha. Bacteriological patterns of chronic suppurative otitis media in Ludhiana. Ind J Med Sci 1996;50(6):191-5.

42. Ballal M, Jyothirlatha, Kishor J, Rajan R, Shivananda PG.

Chronic suppurative otitis media - A bacteriological and mycological study. Ind J Otolaryngology Head Neck 1992;1(1):10-3.

43. Saurabh Varshney, Pratima Gupta. Bacteriological study of chronic suppurative otitis media. Ind J Otol 1999;5(2):8791. 